\title{
APPRAISING THE IMPACT OF ORGANIZATIONAL COMMUNICATION ON WORKER SATISFACTION IN ORGANIZATIONAL WORKPLACE
}

\author{
James Baba Abugre \\ University of Ghana Business School, Legon, Accra, Ghana \\ E-mail: jbabugre@ug.edu.gh
}

\begin{abstract}
Today, more and more businesses depend on communications for their success since a well-organized communication system is shown to be an important factor in stimulating worker satisfaction in organizations. The purpose of this paper is to assess organizational communication and its impact on worker satisfaction in organizational workplace. The paper examines three Ghanaian organizations in the formal sector using a quantitative survey of ninety respondents to gain information for the study. The chi-square test was used with cross-tabulation of the independent and dependent variables to test and answer the hypothesis and research questions formulated for the study. Findings show that there is a significant relationship between efficient organizational communication and employee satisfaction. Findings also show that organizational communication has a positive impact on employee performance. Analysis of the findings further reveals that workers prefer good leadership communication behavior because it has positive effects on workers in organizations. The study proposes that organizations in the formal sector will achieve their objectives if they pay proper attention to the communication processes through efficient organizational communication in the workplace.
\end{abstract}

Key words: employee performance, organizational communication, organization, worker satisfaction.

\section{Introduction}

Over the past years many scholars have argued that employee commitment to work is the result of worker satisfaction in organizational workplace. (Meyer and Allen, 1997; Meyer and Herscovitch, 2001; Ng, Vandenberg, and Wilson, 2006). Worker satisfaction and commitment lead to organizational citizenship behavior, reduction in absenteeism and turnover which would benefit the organization (Watson and Papamarcos, 2002). Organizational communication is a process that enables groups and or partners to learn from each other and to coordinate their tasks, helping the group to develop and maintain a viable relationship (Robson, Skarmeas, and Spyropoulou, 2006). In the social constructionist approach, organizational communication can be defined as the way language is used to create different kinds of social structures, such as relationships, teams, and networks. Organizational communication is linked to organizational commitment in several ways. For example $\mathrm{Ng}$, Vandenberg, and Wilson, (2006) found that organizational communication, work schedule flexibility through effective interpersonal communication, and opportunity for learning affect organizational commitment. Effective organizational communication leads to organizational commitment to total quality management (Allen, 1992) and effective organizational communication is key to employee satisfaction (De Rider, 2004).

Extant literature suggests that effective communication between managers and employees help to improve the likelihood of an organization being successful. 


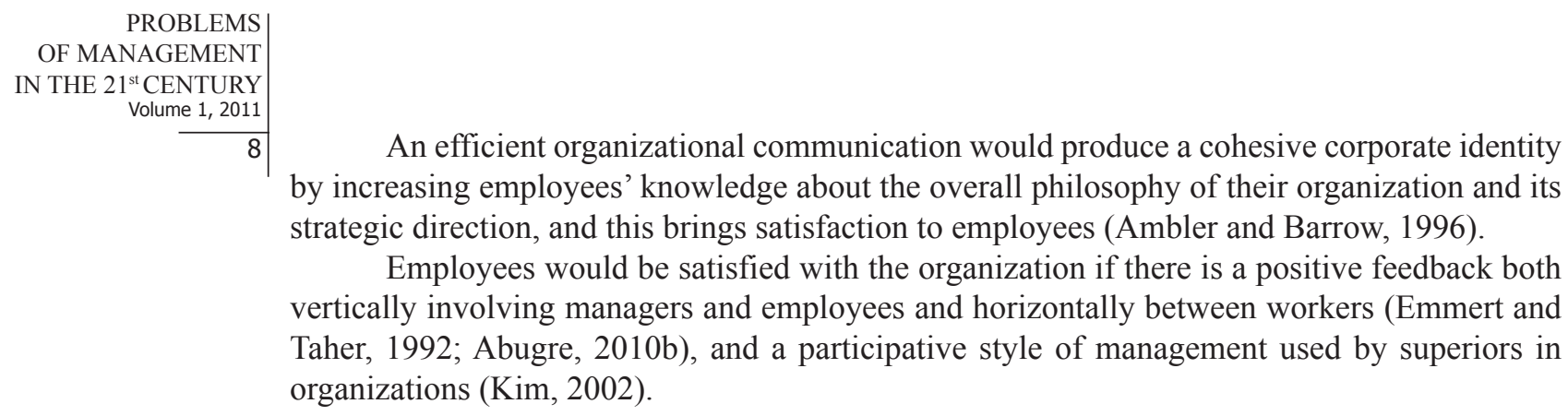

\section{Research Problem}

Although the subject of organizational communication is gaining interest, particularly because it is very essential in all dimensions of the organization's performance (Putnam and Fairhurst, 2001; De Rider, 2004; Abugre, 2010b) yet, existing literature on organizational communication in the context of management in Africa is hardly observed in the global theoretical framework. While the studies above indicate the growing link between organizational communication and worker satisfaction, these studies have largely focused on Western economies (see De Rider, 2004; Meyer and Herscovitch, 2001). There is therefore a deficiency of empirical understanding on the subject matter in developing countries and in particular Africa. Extant literature on organizational communication points to the developed countries whereas theoretical findings from the developing countries are missing. This is a major problem confronting global management research in the $21^{\text {st }}$ century, since as a result of globalization, many industries from the West and East are now moving to Africa as the hub of resources and the latest global market (UNCTAD, 2007). As international trade rises and production is relocated abroad, expatriates are sent to manage the multi-nationals who locate plants and offices in the emerging economies, and therefore must have knowledge of the culture and environment (Teitel, 2005). To increase our knowledge on management systems in developing economies, more research is needed particularly in the unexploited areas of the global intermediary economies like Africa, Eastern Europe, and Asia. For this reason, this article seeks to address this issue by contributing to theoretical literature in organizational communication with a focus on African management practices.

In summary, the existing body of literature is exposed to a number of limitations in terms of scope and context of this work, which this article attempts to address. In terms of context, this paper seeks to address these limitations by exploring the impact of organizational communication on employees' satisfaction and how this could affect organizational work output in a developing context. In terms of scope, the paper focuses on three Ghanaian organizations as case studies, but its findings are relevant to other African countries due to similarities in cultural and managerial practices.

\section{Research Focus}

This study focuses on organizational communication and how effective organizational communication can raise the level of worker satisfaction leading to increased work output in the formal sector. This paper argues that effective organizational communication can lead to greater commitment of the workforce, thereby enhancing motivation and performance of employees. Effective communication between managers and employees in the formal sector can enhance worker relations, organizational networks, and employee trust that would foster good corporate citizenship. The study focuses on three Ghanaian organizations in the formal sector as case studies, but its findings are relevant to other African countries due to similarities in cultural and managerial practices. Therefore, findings of this study are expected to provide a theoretical and practical representation of organizational communication processes in both the formal and 
informal sector organizations. This leads to the following research questions:

RQ1. What is the impact of organizational communication on worker satisfaction? behavior?

RQ2. To what extent does leadership communication behavior affect employee work

Effective communication in organizations enables employees to be clear on information required to carry out their jobs (Adler, 1999). As a result, employees who experience a lack of information about how to perform a task are likely to suffer higher levels of frustration than those equipped with the necessary information to easily negotiate a work task. Therefore, the study hypothesizes that;

Hypothesis: There is a positive relationship between effective organizational communication and worker satisfaction.

\section{Methodology of Research}

The method used for this study is basically a quantitative examination of data collected from three formal sector organizations.

\section{General Background of Research}

The general research approach can be described as a descriptive cross-sectional field survey. The data for the study is primary data and analysis is exploratory. The study is based on an empirical survey of 90 employees of three carefully and conveniently selected public organizations in Ghana. The employees were selected randomly from each of the three companies. Ninety (90) self-developed and self-administered questionnaires were used to solicit information from employees on the role of organizational communication on worker satisfaction.

\section{Sample of Research}

The sample for the three organizations was conveniently drawn from the directory of companies/organizations in Ghana; however, the author made sure that the organizations chosen were all from the Formal sector. Formal sector in this article means organizations that are wholly owned and managed by the government of Ghana with the employees regarded as public sector workers. As a perceptual study, consideration was given to the size of the study organizations hence, the choice of large and established organizations in the formal sector (The Ghana Post, Bank of Ghana, and the University of Ghana Medical School).

With regards to survey of the workers, 90 questionnaires formed the basis of the sample size of the three organizations with a ratio of 30 randomly selected middle and senior level workers of each organization. However, 81 questionnaires were properly filled and returned in the ratio of 26: 31: and 24 from the Ghana Post, Bank of Ghana, and the University of Ghana Medical school respectively. Eighty-one valid questionnaires represent $90 \%$ which is significantly adequate for a survey analysis. No considerations were taken in terms of gender and age, however, the study made sure that the sample size covered all departments and particularly personnel of middle and senior level management.

\section{Research Instrument and Procedures}

The instrument for the study was developed from the literature, and comprised of both closed and open ended questions which enabled the participants to offer their candid opinions 


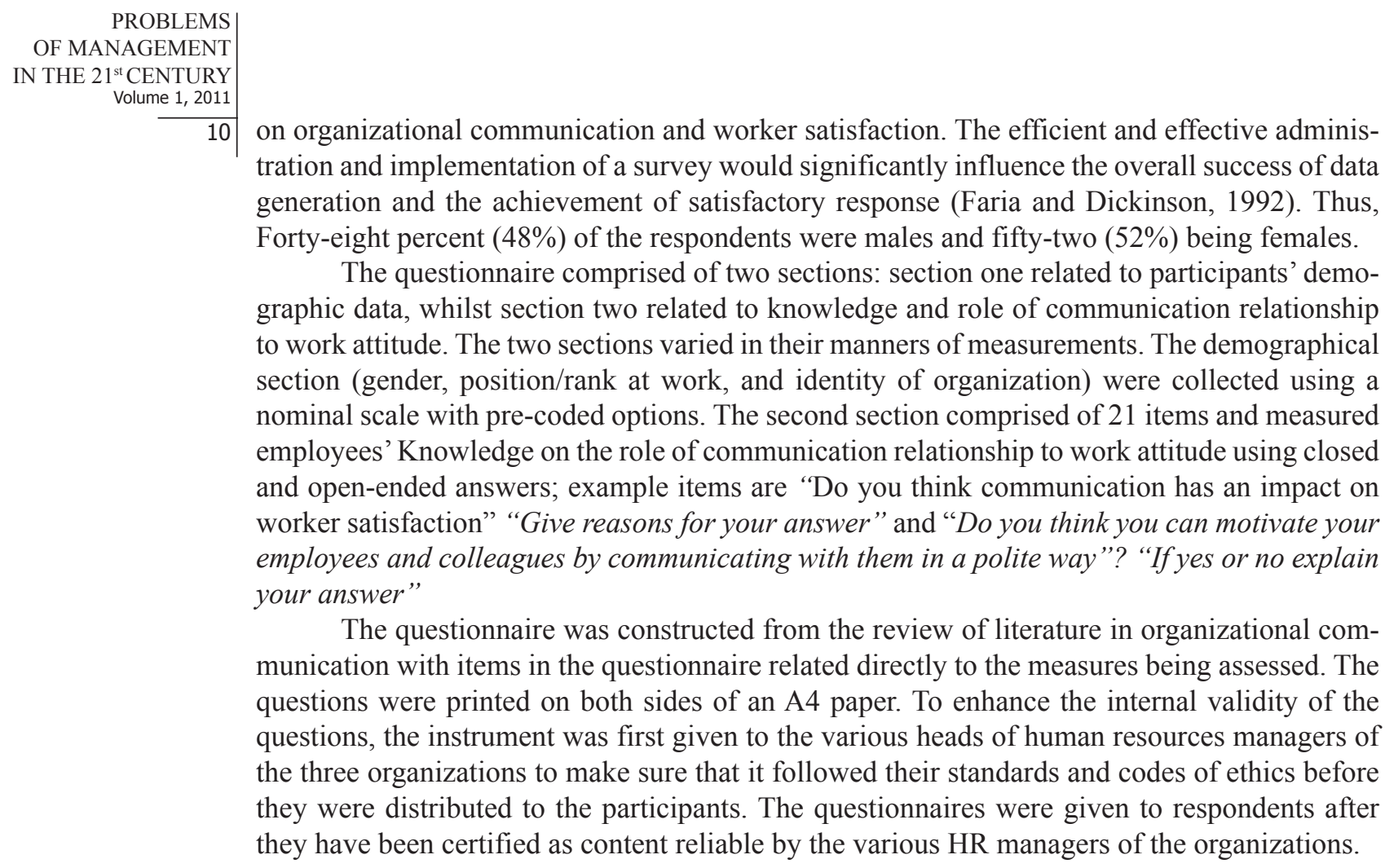

\section{Data Analysis}

The data collected for this study were analyzed using Statistical Package for the Social Sciences (SPSS) version 15.0 to provide descriptive and graphical analyses, the chi-square test, and cross tabulations of the test variables. The premise for the validity and consistency of this study is the calculation of the P-value. The p-value is the probability that a sample drawn from a population is tested given that the assumptions proposed by the study are true. A p-value of $.05 \%$ indicates that there would only be a $5 \%$ chance of drawing the sample being tested if the research proposition was actually true. In other words, it demonstrates a 95\% confidence level meaning that the study has $95 \%$ of assurance that the research questions are significant to provide responses appropriate to the research objectives. A p-value of 0.05 is a typical threshold used in industry to evaluate the stated hypothesis or research questions, and a value below .05 is said to be significant (Tusting, Ligthelm, Martins, and Van Wyk, 2005).

\section{Results of Research}

This section reports the statistical analysis of the research questions and the hypothesis used in the study.

\section{Research Question 1: What is the impact of organizational communication on worker satisfaction?}

On the impact of organizational communication on worker satisfaction, $96.1 \%$ of the total respondents of all three organizations answered 'yes' that there is a strong impact of communication on worker satisfaction in organizations. While only $1.3 \%$ of the total number of respondents said 'No' the satisfaction of workers in the organization does not depend on organizational communication. The remaining $2.6 \%$ of respondents said they don't know if there is an impact of organizational communication on worker satisfaction or not. This is illustrated in the Table I below. 
Table 1. Impact of organizational communication on worker satisfaction (\%).

\begin{tabular}{|c|c|c|c|c|}
\hline \multirow{2}{*}{ Impact of Communication on worker satisfaction } & \multicolumn{3}{|c|}{ Name of Organization } & \multirow[b]{2}{*}{ Total } \\
\hline & Ghana Post & BOG & UGMS & \\
\hline $\begin{array}{l}\text { Yes } \\
\text { No } \\
\text { Don't Know } \\
\text { Total }\end{array}$ & $\begin{array}{c}92.0 \\
4.0 \\
4.0 \\
100\end{array}$ & 100 & $\begin{array}{c}95.0 \\
5.0 \\
100\end{array}$ & $\begin{array}{l}96.1 \\
1.3 \\
2.6 \\
100\end{array}$ \\
\hline
\end{tabular}

Research Question 2: To what extent does Leadership Communication behavior affects employee work behavior?

Ninety-two percent $(92.6 \%)$ of the total respondents of all three organizations reported that leadership communication behaviour has a great impact on employee work behavior in terms of job performance in the organization. While $7.2 \%$ of respondents said leadership communication behavior does not affect the conduct of their work. Thus, the way and manner their bosses speak to them can affect their job performance either negatively or positively. This is illustrated in the Table 2 below.

Table 2. Cross tabulation: impact of leadership communication behavior and workers performance (\%).

\begin{tabular}{|l|l|c|c|c|c|}
\hline \multirow{2}{*}{} & \multicolumn{3}{c|}{ Name of Organisation } & \\
\cline { 3 - 6 } \multicolumn{2}{|c|}{} & $\begin{array}{c}\text { Ghana } \\
\text { Post }\end{array}$ & BOG & UGMS & \multirow{2}{*}{ Total } \\
\hline $\begin{array}{l}\text { Does Leadership communication } \\
\text { behavior affect workers perfor- } \\
\text { mance }\end{array}$ & Yes & 96.2 & 87.1 & 95.2 & 92.6 \\
\cline { 2 - 6 } & No & 3.8 & 12.9 & 4.8 & 7.4 \\
\hline \multicolumn{2}{|c|}{ Total } & 100.0 & 100.0 & 100.0 & 100.0 \\
\hline
\end{tabular}

Similarly, results from the survey show that motivation of employees plays a major role in job satisfaction and productivity in work organizations. In this work, the paper sought to find out if workers can be motivated by the presence of good organizational communication. From the survey results, with the exception of Ghana Post that $96.2 \%$ of respondent said 'yes' while $3.8 \%$ of respondents said 'No', the rest of the organisations recorded $100 \%$ response rate to the issue of polite communication and motivation as an index of worker satisfaction and increase productivity.

Table 3. Cross tabulation: impact of leadership communication behavior and workers motivation (\%).

\begin{tabular}{|l|l|c|c|c|}
\hline \multirow{2}{*}{} & \multicolumn{3}{c|}{ Name of Organisation } \\
\cline { 3 - 5 } \multicolumn{2}{|c|}{} & Ghana Post & BOG & UGMS \\
\hline \multirow{2}{*}{$\begin{array}{l}\text { Will polite communication motivate employ- } \\
\text { ees to work and increase productivity? }\end{array}$} & Yes & 96.2 & 100 & 100 \\
\cline { 2 - 5 } & No & 3.8 & 0 & 0 \\
\hline \multicolumn{2}{|c|}{ Total } & 100 & 100 & 100 \\
\hline
\end{tabular}


Following the analysis of the results, we tested the hypothesis via a Chi-Square test to determine the relationship between organizational communication and worker satisfaction. Worker satisfaction was the dependent variable. The test results show that there is a significant relationship between organizational communication and worker satisfaction in organizations as the chi-square analysis illustrates $\left(\chi^{2}=17.836 \mathrm{df}=8, \mathrm{p}<0.05\right)$, where the $\mathrm{p}$-value $=0.02$ is less than the level of significance at 0.05 .

\section{Role of Organizational Communication}

In order to solicit respondents' views on the importance of organizational communication, participants of the study were asked to state in their own opinion the main functions of communication in their organizations. Thirty-seven percent $(37.0 \%)$ of the respondents said communication is used to deliver instructions; $30.9 \%$ said communication is used for basic information needed for job; $12.9 \%$ said communication is used to resolve work related issues; $9.9 \%$ said communication is used to encourage dialogue and team building, while $9.3 \%$ said communication is used to motivate staff to work.

\section{Frequency of Communication Media Used by Workers}

The study also sought to examine how communication channels were used in terms of preference in the various organizations. Results show that the most frequent channels of communication used by workers in their organizations are: face-to-face communication $65.4 \%$; memos and letters $12 \%$; formal meetings $9.9 \%$; email $4.9 \%$; telephone $3.7 \%$, and informal meetings $2.5 \%$.

\section{Communication as an Important Organizational Process}

Analysis of results showed that among the organizational processes, $86.4 \%$ of respondents believe that communication is very important, while $12.3 \%$ say communication is important in the organisations and therefore good organizational communication gives them satisfaction.

\section{Assessment of Communications in Organizations}

Respondents were asked to assess the effectiveness of their organizational communication with the descriptors very effective, effective, somehow effective, and not effective. Results show that $40.7 \%$ of respondents say communication is very effective; $37.0 \%$ of respondents say effective; $19.8 \%$ of respondents say somehow effective, and $2.5 \%$ of respondents say communication in their organizations is not effective.

\section{Discussion}

The main purpose of this study was to gauge workers perception on how organizational communication impacts employees' satisfaction in organizational workplace. Results emerging from the analysis show that there is a significant relationship between effective organizational communication and worker satisfaction. This is illustrated by the test of the hypothesis which states that 'there is a significant relationship between effective organizational communication and worker satisfaction' and which is reasonably supported by the data collected. The strength of this test is further illustrated by the likelihood ratio statistics which is 0.3 and is less than 
the critical value at a significant level 0.5. A further analysis of the responses of the employees show that good and modest communication from organizational leadership to employees will motivate workers to be satisfied to give off their best.

Consistent with past research (De Rider, 2004; Abugre, 2010a), this study found that effective organizational communication displays a direct and positive relationship with job satisfaction and positive commitment of employees at the organizational level as a result of general employee satisfaction. This finding effectively responds to the first research question (RQ1). The strength of the answer to RQ1 is further demonstrated by the fact that two of the organizations, BOG and UGMS have $100 \%$ and $95 \%$ response rate respectively from their employees authenticating without any uncertainty that organizational communication has a strong impact on employee satisfaction (see Table 1). The findings add support to the general belief that effective organizational communication affects employees' attitude to work as a result of worker satisfaction with communication (Maertz and Griffeth, 2004; Kim, 2002; Abugre, 2010b).

Findings of the study also showed that good and effective communication from leadership in the formal sector can affect employees' work behaviors in a positive manner and consequently affect organizational work output. This finding is a response to the research question (RQ2) which sought to find whether effective leadership communication can affect employee work behavior. Findings further showed that effective organizational communication has a significant impact on worker satisfaction, and this is illustrated in Table 2.

An analysis of the findings also revealed that among all the organizational processes like employee performance appraisal, employee training and development, employee welfare system, etc., communication is the most important of all and that effective organizational communication would support all other processes to be efficient. As many as $86.4 \%$ of the total respondents agreed that organizational communication is very important and comes first to all other organizational processes. Findings from the study also showed that among the organizational media/channels of communication used in the Ghanaian public organizations, face-toface communication is the most used and preferred choice of workers, second by letters and memos, and then formal organizational meetings. However, the use of email and telephone conversation recorded very low ratings in terms of usage, as low as $4.9 \%$ and $3.7 \%$ respectively. These findings emphasis the problem of technology deficiency in developing countries. Whilst electronic media plays a major role in today's global world, many workers in African countries have no access to these technologies. This certainly is an impediment to development, because global knowledge revolves around information and communication technology.

This paper has demonstrated interesting findings of the study, there are however some limitations inherent in its approach. First, the author believes that three different organizations may not be sufficient to generalize the findings particularly in the large Ghanaian formal sector. Also, the number of participants for the study may appear small for a perceptual study and therefore more participants could have been employed. The author thus encourages a replication of this study in other areas with larger sample size numbers. Also, a replication of this study through the use of Downs (1990) Communication Audit Questionnaire is encouraged to test the empirical communication satisfaction of employees.

\title{
Conclusion
}

The significance of effective organizational communication is very critical in retaining worker satisfaction and consequently worker performance in organizations. Effective organizational communication can be possible if organizational leadership improve on their communication methods and create unrestricted access of communication media to their workers. The consequences of poor organizational communication would result in an increased turnover rate of employees in the organization due to a lower level of worker satisfaction.

\author{
PROBLEMS \\ OF MANAGEMENT \\ IN THE $21^{\text {st }}$ CENTURY \\ Volume 1,2011 \\ 13
}


PROBLEMS

OF MANAGEMENT

IN THE $21^{\text {st }}$ CENTURY

Volume 1, 2011

14

The findings above have both theoretical and practical significance to organizational studies, and add our knowledge on managerial practices in several ways. Theoretically, the results highlight some important experiences of organizational communications in Ghanaian work organizations, stimulating more research in the area of communication in developing countries. From a practical point of view, findings of this work confirm that to motivate and retain employees to work hard, effective organizational communication plays a significant role. The work has established the positive impact of good organizational communication on worker satisfaction which ultimately leads to improved work performance in the workplace. Also, the work provides useful guidelines for managerial practice and implications in the area of organizational communication.

\section{Acknowledgement}

The author wishes to thank Rosemary Ansah of BOG, Selie Baiden of UGMS, and Emelia Out for helping in the collection of this project data.

\section{Notes}

This paper is a revised and expanded version of an international scientific paper in the $12^{\text {th }}$ annual conference of the Academy of African Business and Development. The paper was recommended for republication by the conference scientific committee.

The reference for the Conference version is:

Abugre, J. B. (2011). Organizational communication and worker satisfaction in organizational workplace. In. IAABD 2011- Challenges in the Era of Globalization (Conference Proceedings, Edmonton, Canada, May 17-20, 2011). Athabaska University, Canada, p. 440-447.

The funding support for the conference was provided by The University of Ghana Business School, Legon.

\section{References}

Abugre, J. B. (2007). Organizational Communication. In: Puplampu, B. (Eds), Management in Action, with a Twist of Theory. Accra: Sedco, p. 40-54.

Abugre, J. B. (2010). Essentials of Employee Communication; empirical evidence for theoretical and managerial practice. Saarbrücken: $\mathrm{GmbH} \& \mathrm{Co}$, Lambert.

Adler, R. (1999). Communicating at Work: Principles and Practices for Business and the Professions. Boston: McGraw-Hill College.

Allen, M. W. (1992). Communication and organizational commitment: perceived organizational support as a mediating factor. Communication Quarterly, Vol. 40, No. 4, p. 357-67.

Ambler, T., Barrow, S. (1996). The employer brand. Journal of Brand Management, Vol. 4, No. 3, p. 185-206.

De Ridder, J. (2004). Organisational communication and supportive employees. Human Resource Management Journal, Vol. 14, No. 3, p. 20-30.

Emmert, M., Taher, W. (1992). Public Sector Professionals: The Effects of Public Sector Jobs, Job Satisfaction and Work Involvement. American Review of Public Administration, Vol. 22, No. 1, p. 37-48. 
James Baba ABUGRE. Appraising the Impact of Organizational Communication on Worker Satisfaction in Organizational Workplace $\mid$\begin{tabular}{l} 
PROBLEMS \\
OF MANAGEMENT \\
IN THE $21^{\text {st }}$ CENTURY \\
Volume 1,2011 \\
\hline 15
\end{tabular}

Faria, A. J. and Dickinson, J. R. (1992). Mail survey response, speed and cost. Industrial Marketing Management, Vol.21, p. 51-60.

Kim, S. (2002). Participative Management and Job Satisfaction: Lessons for Management Leadership. Public Administration Review, Vol. 62, No. 2, p. 231-241.

Meyer, J. P., Allen, N. J. (1997). Commitment in the Workplace. Theory, Research, and Application. Thousand Oaks: SAGE.

Meyer, J. P., Herscovitch, L. (2001). Commitment in the workplace. Towards a general Model. Human Resource Management Review, Vol. 11, No. 3, p. 299-326.

Ng, T. W. H., Batts, M. M., Vandenberg, R. J., Dejoy, D. M., Wilson, G. M. (2006). Effects of management communication, opportunity for learning, and work schedule flexibility on organizational commitment. Journal of Vocational Behavior, Vol. 68, p. 474-489.

Putnam, L. L., Fairhurst, G. T. (2001). Discourse analysis in organizations. In: Jablin, F. M., Putnam, L. L. (Eds), The new handbook of organizational communication. Thousand Oaks: SAGE, p. 78-136.

Robson, M. J., Skarmeas, D., Spyropoulou, S. (2006). Behavioral attributes and performance in international strategic alliances: review and future directions. International Marketing Review, Vol. 23, No. 6, p. 585-609.

Teitel, S. (2005). Globalization and its disconnects. Journal of Socio-Economics, Vol. 34, p. 444-470.

Tusting, D. H., Ligthelm, A. A., Martins, J. H. and Van Wyk, H.J. (2005). Marketing Research in Practice, Pretoria: UNISA Press.

UNCTAD (2007). World Investment Report in transnational corporations, extractive industries and development. Geneva: United Nations Publications.

Watson, G. W., Papamarcos, S. D. (2002). Social capital and organizational commitment. Journal of Business and Psychology, Vol. 16, No. 4, p. 537-52.

Advised by Laima Railiene, University of Siauliai, Lithuania

Received: April 22, 2011

Accepted: May 27, 2011

\begin{tabular}{ll}
\hline James Baba Abugre & Lecturer, University of Ghana Business School, Box LG 78, Legon, Accra, \\
& Ghana. \\
& Phone: +233244924323. \\
& E-mail: jbabugre@ug.edu.gh \\
& Website: http://www.ugbs.edu.gh/site/
\end{tabular}

